\title{
The Impact and Opportunities of COVID-19 in Ghana
}

\author{
Richard Sam Dickson* (1), Deli Yao \\ School of Economics and Management, Anhui University of Science and Technology, Huainan, China \\ Email: *dicksonrichard@outlook.com
}

How to cite this paper: Dickson, R. S., \& Yao, D. L. (2020). The Impact and Opportunities of COVID-19 in Ghana. Open Journal of Social Sciences, 8, 71-86.

https://doi.org/10.4236/jss.2020.810006

Received: September 3, 2020

Accepted: October 12, 2020

Published: October 15, 2020

Copyright $\odot 2020$ by author(s) and Scientific Research Publishing Inc. This work is licensed under the Creative Commons Attribution International License (CC BY 4.0).

http://creativecommons.org/licenses/by/4.0/

\begin{abstract}
The Coronavirus (COVID-19) has recently abstracted the world's most excellent focus. Until mid-August, the number of confirmed cases reached more than 945,165 in Africa with Ghana being third with the highest number of reported cases $(42,210)$. This paper will introduce Ghana and the African continent's virus effects. This perspective aims to update the prevalence and inform about COVID-19 in Ghana, and also explores the economic impact of the global pandemic on a developing country like Ghana, Ghana's responses, opportunities presented and strategies in combating the virus.
\end{abstract}

\section{Keywords}

COVID-19, Impact on the African Continent and Ghana, Responses, Economy, Opportunity

\section{Background}

After China registered the first new coronavirus disease in Wuhan, the entire world is dealing with the novel coronavirus. In their regular update on $17 \mathrm{Au}$ gust 2020, the World Health Organization (WHO) announced that there are $21,294,845$ cases and 761,779 deaths worldwide (WHO, 2020). Table 1 shows the confirmed and death cases of COVID-19 in respect to the various continents.

The World Health Organization (WHO) formally recognized the novel coronavirus disease as a pandemic as it spread to over 100 countries, leading to tens of thousands of cases within months (Rettner, 2020). Countries like the United States, Brazil, India, Russia, Spain, Italy, etc. have been most affected worldwide. Novel coronavirus disease is now a public health crisis, a virus that was originally contained to China's borders has now broken out in every corner of the world 
Table 1. COVID-19 confirmed cases and deaths.

\begin{tabular}{ccc}
\hline Region & Confirmed Cases & Deaths \\
\hline Africa & 945,165 & 18,476 \\
Americas & $11,420,860$ & 414,326 \\
Eastern Mediterranean & $1,723,673$ & 45,704 \\
Europe & $3,754,649$ & 214,092 \\
South-East Asia & 3040,168 & 59,875 \\
Western Pacific & 409,589 & 9293 \\
Total & $21,294,845$ & 761,779 \\
\hline
\end{tabular}

Source: Coronavirus disease (COVID-19) Situation Report-181 Highlights Situation in numbers (by WHO Region) (WHO, 2020).

(Horowitz, 2020). The economic effect of the novel coronavirus is intolerable, as countries have begun lockdowns in cities and small towns. In every area, economic pressure was felt from travel bans affecting the aviation industry, sporting event cancelations affecting the sports industry, the hospitality industry, the banking sector, the financial markets, the event industry, the entertainment industry, the ban on mass gathering affecting events and the entertainment industry (Horrowitz, 2020; Elliot, 2020).

In Africa, South Africa (583,653 total confirmed cases), Nigeria (48,770 total confirmed cases), and Ghana (42,210 total confirmed cases) are the top three countries with the highest recorded cases (WHO, 2020). Ghana's Government issued a lockdown in two of its regions in the early stages of the outbreak in Ghana. This lockdown was to be issued in selected cities and specific instructions to be implemented.

All external borders have been closed, public meetings have been canceled, including conferences, workshops, funerals, concerts, pollical rallies, sporting events, and religious activities, such as church services and mosques. Private burials with no more than 25 mourners were permitted. Both colleges, high schools, and elementary schools were closed until further notice. The Attorney General was led to the parliament to present emergency legislation. The Minister for Health has been given further orders to exercise his authority under section 169 of the Public Health Act 2012 (Act 851) (Ditu, 2020).

Great damage has been done to the entire supply chain such as manufacturing, shipping, restaurants, and other sectors. Consequently, the adverse effect is inevitable. Nonetheless, people should pay more attention to the positive side, in the face of the hasten effect.

This paper would examine the effects of the virus on both Africa and the Ghana region, the strategic responses adopted by Ghana, the impact of COVID-19 on the economy of Ghana, opportunities, and solutions to help combat the pandemic in Ghana. 


\section{The Impact of COVID-19 on Africa}

Africa as a continent has relatively low novel coronaviruses cases in contrast with the rest of the continents. In its report, WHO cautioned that, in the first year, the pandemic may kill 83,000 - 190,000 people from 47 African countries, depending largely on government response; and that the social-economic impacts that "lurk" over many years (BBC Africa, 2020). Also, there is not one homogenous native around the COVID-19 pandemic, as in other countries, in Africa. The pandemic affects each nation differently, despite varying strengths and weaknesses. As a result of the rapid spread of the novel coronavirus which first happened in Egypt on 14 February 2020 and spread two months later to countries very much in Africa, African countries are closing their borders and other countries have introduced robust lock-up strategies with contact tracing to map transmission and isolating suspected individuals from infection (WHO Africa, 2020).

Government handling of the 2019 new coronavirus (COVID-19) pandemic may be addressed but most countries today have strategies to limit the spread of the coronavirus by significantly restricting social interaction. The effects of these strategies on the economy and related effects on social determinants of health are now becoming increasingly concerned. Governments and community organizations may be prepared to spend to combat the immediate impacts of the crisis on health social determinants but the expense of such spending in the future will be considerably overlooked, combined with decreased access to healthcare and decreased expenditures on health social determinants (Karnon, 2020).

While some countries including Uganda and South Africa introduced expert committees to help direct the government, Ghana as a nation assessed its resources and economy and then opted against a complete lockdown, a partial lockdown in some major cities and neighboring areas. Although others formed mobile teams to tackle contaminated COVID areas, Rwanda reduced congestion in its food markets and established health facilities in key rural-urban public centers (Africa Center for Strategic Studies, 2020).

Such concerted acts by African leaders or governments are to help flatten COVID cases, as a rise in COVID cases means a burden on health systems and the economy as a whole. Despite fewer hospital beds, lower doctor-to-patient ratio, most African countries would be unable to cope with increased cases of COVID (WHO Africa, 2020).

As a consequence of the imposed partial or complete economic lockdown brought on by the latest coronavirus pandemic, the expected GDP growth of Africa, which will hit $3.2 \%$ by 2020 , is now projected to decrease by $-0.8 \%$. Economic losses in eastern Africa such as Kenya, Ethiopia, Tanzania, Uganda, etc. A decrease in tourism, export sales, and supply chain instability has taken Kenya's GDP to $1 \%$, a steady rise of about 5.7 percent. GDP growth in Ethiopia has been revised to 3.2 percent from 6.2 percent in 2020, with higher unemployment levels. From $3.5 \%$ to $1.85 \%$ in Uganda, and $3.3 \%$ - $2 \%$ in Tanzania due to global 
supply chain instability and reduced demand for consumer products (Deloitte, 2020).

Africa's debt issues are rising at an alarming pace. The $2-3$ percent decline in GDP growth levels due to COVID-19 means that initial debt burdens become a concern. With America and Europe paying close to zero interest rates on 10 years' government bonds, Africa pays $5 \%-6 \%$ on the same ten years of government bonds. Africa is still at a disadvantage (Mutize, 2020).

Before Africa had been faced with COVID-19, several countries had relatively small national debts with a debt to GDP ratio of $60 \%$, with Sudan, Eritrea, Cape Verde, and Mozambique having a debt to GDP ratio of more than 100\% (IMF, 2020). Debt rates are rising due to borrowing additional funds by some African countries to offset the immediate effect of the COVID-19 crises. Most African countries would have to return to the highly indebted poor countries (World Bank and IMF initiative HIPC) (Ekeruche \& Onyekwena, 2019).

According to the IMF, Africa will be expected to control its coronavirus by an estimated US\$114 billion in 2020 (Georgieva, 2020). Many African countries rely on external funding to complete their annual budget spending, countries like Ethiopia may see a decline in external funding during this COVID-19 period. The countries most affected would be countries that rely on substantial foreign funding, as health spending is extremely high and the most important priority (Avila et al., 2013). Africa faces the much greater problem of the management of not only COVID-19 but also of ensuring that the bulk of its resources are not channeled to COVID-19 to leave malaria, HIV/AIDS, and TB, among others, with an enormous gap in the global economy. Therefore, it would be a big challenge in West Africa to sustain a sufficient health budget to resolve all existing health issues, and not just COVID-19 (Schneider et al., 2020).

According to the global health agency, the World Health Organization, up to 44 million people may suffer from COVID-19 in Africa if the virus is not contained (WHO Africa, 2020). Africa has, in general, a weak healthcare system due to poor governance and policies resulting from loans from the International Monetary Fund. With established UK and US health systems over-stretched, that of Africa comes into question (Poitras, 2020). Continent Africa produces a great deal of tourism revenue. According to IATA (2020), the Aviation industry contributes 55.8 billion dollars in Africa, providing 6.2 million jobs and contributing $2.6 \%$ of GDP on the continents (PROPARCO, 2016; IATA, 2020). The major airlines in Africa are South African Airways, Kenya Airways, Ethiopian Airlines, and EgyptAir. Countries following the WHO criteria means that international travel limits and border closures mean that airline workers are partially unemployed (IATA, 2020). A ban on international air flights in the tourism value chain means that jobs in this value chain suffer (PROPARCO, 2016). As a result of COVID-19's effect on the tourism industry, Africa could lose 50 billion USD of revenue and 2 million direct and indirect jobs (PROPARCO, 2016).

Most African countries generate oil revenues, with oil prices collapsing historically for the first time in several years from USD 61.5 a barrel in December 
2019 to USD 23.2 a barrel in March 2020. Oil rents in Africa constitute 4.5\% of our GDP (OECD/ATAF/AUC, 2019). For every African nation, the COVID-19 crisis will be felt differently. The COVID-19 crisis will be felt most by countries in Africa that have other problems such as food safety, health infrastructure, etc. Burkina Faso, for example. Mali, Niger, now suffering from a food crisis, which has undernourished 2.5 million children. Countries that rely heavily on food imports will suffer at border close. In those nations, food prices will increase (Gambia, Liberia, Mauritania, and Sierra Leon) (OECD, 2020). Since COVID-19 is a global pandemic, each affected nation has an equal share of the novel coronavirus fight. Africa is importing a significant percentage of its pharmaceutical and protective equipment from Europe and other COVID protective gear and medication rises, a price rise has limited the supply of such goods to the African Continent. From Table 2, it can be seen that around $90 \%$ of pharmaceuticals are supplied from outside the continent, which means that Africa is in serious problems (ECA, 2020).

According to Hoyt 2020, the crashing of the global economic downturn has a major impact on sub-Saharan African countries. Indigenous companies, which are mostly small-scale enterprises, will have to lay off their workers due to lockdowns, and people would find themselves without paycheck contributing to increased poverty. Due to the slower growth rate of developed economies, African countries will have a tough time. Africa's continent faces simultaneous public health and economic crisis that risks crippling healthcare systems, damaging livelihoods, and weakening the region's development prospects for years to come. Africa already has its fair share of issues to tackle, such as the slowdown in growth and overall poverty reduction, at different rates across African countries. The COVID-19 crisis in Africa could reverse years of development gains (OECD, 2020a).

\section{Ghana in the Face of COVID-19}

Ghana has entered the ranks of countries around the world that are implementing some form of movement restriction, aiming to slow down the spread of the SARS-COV-2 the virus that causes COVID-19. The restrictions on movement in

Table 2. African medical \& pharmaceutical products import table.

\begin{tabular}{cc}
\hline Country & Medical and Pharmaceutical products import (\%) \\
\hline EU & $51.5 \%$ \\
India & $19.3 \%$ \\
Switzerland & $7.7 \%$ \\
China & $5.2 \%$ \\
US & $4.3 \%$ \\
UK & $3.3 \%$ \\
\hline
\end{tabular}

Source: Economic Impact of the COVID-19 on Africa; ECA (2020). 
Ghana was scheduled to last for two weeks as the Ghana Health Services and the Ministry of Health to catch up with the marauding virus (Aljazeera, 2020; Quakyi, 2020).

Ghana's first COVID-19 virus case was reported on $13^{\text {th }}$ March 2020. COVID-19 has gradually audited the State of Affairs in Ghana, concerning health, economy, and infrastructure. Ghana's response to COVID-19 has widely been praised as well as managed. Ghana's response was scientific, competent, and realistic. Its key response was the education on COVID-19, which was on handwashing with soap, the use of hand sanitizers, and social distancing. On the other hand, tracing and limited testing has been the Ghana Health service strategy to reduce the spread (Lexology, n.d.). Table 3 provides an overview of some of the restrictions that were imposed in Ghana due to COVID-19.

The government set up an inter-ministerial committee on the response to coronavirus headed by President Nana Addo Dankwa Akufo-Addo in response to this pandemic. The committee concentrated on restricting and preventing the introduction of the virus, controlling its spread; providing adequate treatment to the sick; reducing the social and economic effects of the virus; and encouraging expanded domestic skills and increasing self-reliance.

In view of the fact that COVID-19 has already started to slow down economic activity and the effect of COVID-19 continues to spread, apart from introducing steps to boost economic growth, the government is trying to cut expenditures including Capex (Deloitte Ghana, 2020).

Measures established and adopted to stimulate economic growth include (Deloitte Ghana, 2020; Ofori-Atta, 2020; Africa Center for Strategic Studies, 2020):

1) To promote economic recovery, the Government of Ghana has launched a Coronavirus Alleviation Program (CAP).

2) The new Ceiling on the Stabilization Fund for Ghana has been reduced from $\$ 300$ million to $\$ 100$ million to allow excess transfers of funds to the Account.

3) Goods \& Services and Capex spending was balanced down GHS 1.2 bn.

4) The Petroleum Revenue Management Act (PRMA) has been amended to allow the Heritage Fund to withdraw funds to aid in the battle against COVID-19.

Table 3. Laws are imposed in Ghana due to COVID-19 and their respective timeline.

\begin{tabular}{|c|c|}
\hline Dates & Laws Imposed \\
\hline March 16, 2020 & $\begin{array}{l}\text { Schools were closed and social distancing re-emphasized with } \\
\text { a ban on public gatherings. }\end{array}$ \\
\hline March 22, 2020 & The border was closed to international passengers traveling to Ghana. \\
\hline March 30, 2020 & $\begin{array}{l}\text { A three-week lockdown was imposed restricted to the Greater Accra region } \\
\text { (which encapsulates Accra and the port of Tema), Kumasi, and other } \\
\text { parts of the Ashanti region. These were regions with the most cases. }\end{array}$ \\
\hline
\end{tabular}


5) The Bank of Ghana Act has been amended to allow Ghana's government to borrow from the Bank of Ghana more than the stimulated threshold if necessary.

6) Commercial banks committed to providing syndicated GHS 3 bn facility to help key industries in granting a six-month moratorium on major repayments to selected companies, and reducing interest rates by 200 basis points, as well as rising private sector credit supply.

7) The Government is also introducing the following fiscal steps to reduce the company and household effects of the pandemic:

a) Extension of the due dates to file tax returns from normal 4 months to 6 months after the ban year ends.

b) Grant of waiver of interest on key tax liabilities held by taxpayers who will refund their outstanding liabilities by June 30th, 2020.

c) Exemption from duties on defined contributions from third-tier pension funds.

d) Grants of the income tax deduction for contributions from the private sector, and grants to counter the COVID-19 pandemic.

e) Establishment of an e-mail filing and direct transfer payment system allowing taxpayers to file and pay taxes remotely with the different Ghana Revenue Authority (GRA) offices.

The President of Ghana Nana Addo Danquah Akuffo Addo proposed 4 benefits for health workers on April 5 (Zhang, Nonvignon, \& Mao, 2020):

a) A three-month exemption from paying taxes on their emoluments of jobs beginning in April 2020. (The President continued this for another three months in his 13th address.)

b) A daily payment of 150 Ghanaian cedis (roughly \$26) for contact tracing staff.

c) An extra payment of 50 percent of the basic monthly salary for front-line health workers beginning in March for four months. Since then, the grant has been extended by 3 months.

d) An insurance package of 350,000 cedis covered (about 60,345 dollars). On 23 July, it was increased to 10 million cedis.

Figure 1 shows the COVID-19 confirmed cases in respect to the various regions in Ghana.

\section{The Impact on Ghana's Economy}

The COVID-19 pandemic has impacted Ghana's economy's supply-side with industries, hotels, shops, and offices closed due to the lockdown that has seriously affected salaries (regular, weekly, and monthly) of both traditional and modern household workers who are currently unable to participate in any profitable trade as markets are partially closed in line with public transport restrictions. Similarly, people have been locked home with no customers, no visitors, no shoppers, and no passengers on the demand side of the economy, thereby dramatically affecting the regular, weekly, and monthly household profits. 


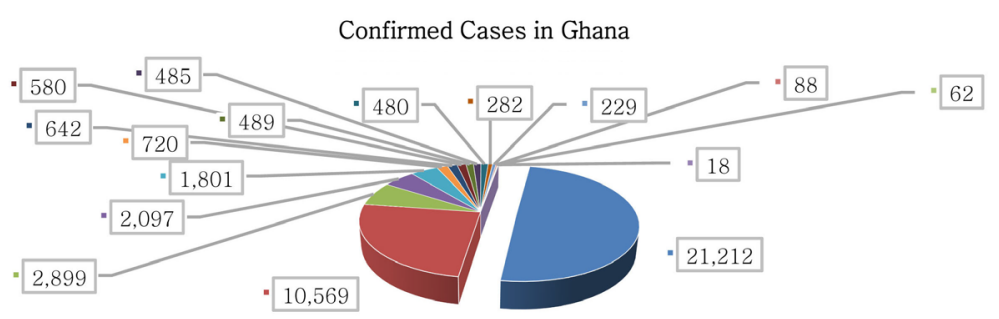

$\begin{array}{lll}\text { " Greater Accra Region } & \text { "Ashanti Region } & \text { " Western Region } \\ \text { "Eastern Region } & \text { "Central Region } & \text { "Bono East Region } \\ \text { - Volta Region } & \text { - Western North Region } & \text { "Northern Region } \\ \text { - Ahafo Region } & \text { " Bono Region } & \text { " Upper East Region } \\ \text { " Oti Region } & \text { "Upper West Region } & \text { "Savannah Region } \\ \text { " North East Region } & & \end{array}$

Figure 1. Confirmed cases in Ghana in respect to the various regions. Source: COVID-19 Updates|Ghana. data sourced from https://ghanahealthservice.org/covid19/ data reports as of August 24, 2020 (Ghana Health, 2020).

According to Danquah \& Schotte (2020), in Sub-Saharan Africa, the World Bank forecasts that economic growth will drop from $2.4 \%$ by 2020 , to $-2.1 \%$ by 2020. The Minister for Finance of Ghana changed the country's projection for the economic growth of $6.8 \%$ to $1.5 \%$ for 2020 downward. Low-income workers are severely affected, in particular informal workers who earn a daily living and have little or no access to healthcare or social safety network. Thus, Nana Agyei Yeba-Mensa wrote that the COVID-19 pandemic presents significant risks not just for people, but also for their economic well-being. The government's mobility constraints and the social distancing steps introduced mean a slowdown in production in a scenario of partial economic lockdown. Although events on the coronavirus pandemic are still unfolding, a preliminary analysis of the effects of the Coronavirus threat to the real sector indicates that the real GDP growth rate expected for 2020 may fall from $6.8 \%$ to $2.6 \%$ in case of infected cases and $1.5 \%$ in case of partial lock-down. In the event of a complete lockout, the expected growth will deteriorate further (Ndour, 2020).

Ghana is one of the steadiest political countries in the region. Public debt is also projected to rise, according to the IMF, although Ghana is already at a "high risk of debt distress." Nevertheless, at the end of 2019, public debt amounted to 67 percent of GDP, representing a comparatively high 450 percent of tax revenue. Since Ghana is an IDA state and its public service is heavily in debt, bilateral creditors could be required to delay debt payments (and not to the private market) (Danquah \& Schotte 2020).

The revenue from the oil exports will drop drastically, it is predicted that the lowest price level since 2002 and nearly half of the projected oil price would drop considerably in 2020, as the price of Brent drops to less than USD 25. Ghana's other main export crop, Cocoa, which accounted for 10 percent of Ghana's current account receipts in 2018, was further reduced by about 10 percent in export revenues. Remittances and tourism (which accounted for around 11 percent of current account receipts in 2018) are also likely to decline, as they accounted for 
just 4 percent of current account receipts in 2018. Therefore, Ghana's current account receipts are down dramatically. However, the downward trend in export revenues is not expected to change, considering the 15\% rise in the average Gold price over 2019 (which accounts for around 23\% of export revenues in 2018) (Debuysscher, 2020). This will have a huge effect on countries heavily dependent on the export of fuel. Fuel exports currently account for $23.3 \%$ of Ghana's overall exports. This suggests that if the epidemic were to spread, the effect would be immersive on export revenues.

The African continent has about $60 \%$ of its population in agriculture, with the agricultural sector being the lifeblood of Ghana's economy, without a doubt, government measures such as restrictions on public gathering, restricted movements, significantly influenced the supply of farm inputs and other farm services. Farm supply prices skyrocketed with the challenges in acquiring day-old imported chicks being a problem. It is slowly becoming difficult to find feed ingredients such as soybean meal, wheat bran, and layer/broiler concentrate (mostly from domestic sources). A significant decrease of people in market centers and the closure of borders have, in one way or the other, affected food production and availability. Most farms in Ghana are rainfed, indicating that these lands depend solely on rain for irrigation. Farmers of these farmlands are monitoring the weather conditions for plowing and planting (Abroquah, 2020). Disruption could restrict farmers' access to inputs such as seeds, fertilizers, and insecticides, confusion, and fear could harm seeding decisions, as well as could the amount of key agricultural exports, due to the overall pandemic decline in world economic activity. General food supply shortages are likely if the pandemic increases. This can lead to food prices inflation, in particular rice, wheat, poultry, and other meat products, fruits, sugar, and other commodities (Ndour, 2020).

COVID-19 could have a huge effect on investment in Ghana. These effects will emerge from projected declines in FDI and portfolio investment, capital flight, domestic financial pressure, and less foreign-source financing opportunities. As a result of the Coronavirus outbreak, the United Nations Conference on Trade and Development (UNCTAD) has already estimated that global FDI could decline by $5 \%$ to $15 \%$ by 2020 . Another reinforcement of the concern of an FDI slowdown is the fact that the top 5000 multinational corporations (MNCs) have already revised their income forecasts by $9 \%$ on average. The most severely impacted developed countries will be MNCs, with profit now estimated to decrease by $16 \%$. A reduction in MNC income will reduce FDI since benefit reinvestments constitute a large part of FDI (UNCTAD, 2019). Scheduled FDI flows slowed down in 2020 due to uncertainties surrounding the impact of COVID-19. As a result of closing borders in Ghana, and in many cases, restrictions imposed in their own country of origin, foreign investors could not enter the country to carry out or even conduct feasibility studies.

Closing schools for nine months means that 7.2 million children are given 9 months less education, including 2.8 million children who are not offered school meals. That will make any child less efficient in its adult years. In total, Ghana's 
social cost of closing schools is estimated to be roughly GHS 14.9 billion (USD 2.6 billion), the existing income loss benefit for 7.2 million children for the next 50 years (Copenhagen Consensus Center, 2020).

The global trend in flight cancelations, border closing, and the need to retain social distance, including the ban on public gatherings, have tremendous negative effects on the hospitality sector's economic activities. Hotels, airlines, tourist spots, and attractions, and car rental services are some of the greatest hits. Hotel occupancy rates have dropped from 70 to less than 30 percent and workers are sent home. And before the consequences of the lockdown, which was later lifted, the average patronage decline in restaurants was already 60 percent. Transport systems have become one of the hardest hits because of social isolation, school cuts, and the prohibition of public meetings (Ndour, 2020).

Closing schools for nine months means 9 months less schooling is provided to 7.2 million children, including 2.8 million children who are not provided school meals. That will make any child in their adult years less productive. In total, the social cost of closing schools for Ghana is expected to be approximately GHS 14.9 billion (USD 2.6 billion), the current value of income loss for 7.2 million children for the next 50 years (Copenhagen Consensus Center, 2020).

The more the virus spreads, the more economic and business performance will be affected, raising concerns about debt sustainability, particularly for highly indebted countries and businesses, absent official support.

\section{Opportunities Presented by COVID-19}

1) Financial Markets

As per the KPMG 2020 report, the pandemic has rattled many, if not all financial markets, and Ghana's have not been left out. Five out of the eight listed banks reported a decline in their share prices, three of which dropped $10 \%$ or more in April for the most part. Ecobank Ghana (EGH) dropped by 20 percent from GHS 8.10 on 31 December 2019 to GHS 6.50 on 21 April 2020, the most affected bank in April. However, circumstances seem to have shifted as EGH's stock price rose to GHS 7.45 on 7 May 2020. Gold has become a secure sanctuary for investors globally with treasury bills and stock prices declining. Gold prices are projected to have a positive effect on the Ghanaian economy, and they will help banks open to the mining industry (Adoteye, 2020).

2) A boost in local products and service production

Reductions in intermediate imported goods in Ghana could significantly slow down production activities. However, reductions in the imports of goods and services are projected to reduce demand for Forex products and services for importation. This has a positive effect on the level of foreign exchange and our net international reserves. It also offers opportunities for import replacement, thereby boosting local products and services production (Ndour, 2020).

3) Developing of a real-time COVID test kit

Ghanaian diagnostic firm, Incas Diagnostics, and a top university, Kwame Nkrumah University of Science and Technology collaborated to create a 
COVID-19 test kit that delivers fast results. A KNUST statement said, "the test which takes 15 - 20 minutes to conduct will allow those tested to know their results in a shorter time to allow health authorities to make decisions in real-time" (Kaledzi, 2020).

4) Local Production Health supplies to help combat COVID-19

The Indigenous Production Titan and (ISO) Accredited company Kasapreko Company Limited reacted positively to H.E's inquiry. The call for local factories to manufacture hand sanitizers to curb the spread of Coronavirus disease in Ghana by President Nana Addo Danquah Akufo Addo. The product is called KCL Hands Sanitizers and the good thing is that it comes in different sizes and it is inexpensive, too. It has enabled the masses to remain healthy and to obey the basic safety measures of sanitizing hands as much as possible (Hammond, 2020).

5) Electricity and Portable drinking water subsidies

In early April, the government announced a policy of electricity and water subsidies in Ghana. Established energy subsidies have been the subject of policy debate for a long time: high prices are often not worth the benefits, particularly as they tend to increase to wealthier households, and subsidies may reduce efficiency as a result of increased power outages. But dialing back energy subsidies after they have been developed is always politically infeasible (Wolfram, 2020).

6) Education Sector

Final year Junior High School (JHS) students and staff of the final year will be given one hot meal a day. This comes after some final year students were stated to have been "hungry to comply with the COVID-19 protocols" (Cromwell, 2020).

7) Health-care delivery

The pandemic COVID-19 has pushed Ghana to strengthen its health-care system. The government this week promised to establish hundreds of new hospitals across the entire West African country. New developments come into action, too. The Silicon Valley Company Zipline uses drones to transport medical supplies and bring samples from suspected coronavirus patients to laboratories in the large cities of Ghana, enabling the government to track the spread of COVID-19 more rapidly (Knott, 2020).

\section{Suggestions}

Many African countries have been swift to introduce containment measures to minimize the spread of the virus even though reported cases have been very few. However, it will be difficult to maintain confining and social distancing, particularly in countries without flexible social protection systems. Most employees across the continent operate in the informal sector and many live through face-to-face transactions on what they receive each day. Also obtaining water, which is so important for prevention and everyday life, needs that many people leave their homes. Testing and touch tracking become less efficient or even impracticable without successful social distancing. Robust compliance does not al- 
ter this reality; indeed, it risks fostering distrust which makes it less likely to comply (OECD, 2020b). By prioritizing, the African governments should build the climate conducive to the development of sustainable health care systems. Governments must work towards encouraging wealth development initiatives, adopt a framework approach that would allow the interdependence of African issues to be understood, and outline how the relatively poor health concerns can be addressed as soon as possible (Klomegah, 2020).

According to Issahaku 2020, financial-market conditions need to be eased to mitigate the detrimental impact of tightening global financial markets. The steps taken by the Bank of Ghana to ease the lending rates and capital requirements are in the right direction. The degree to which this will result in lower lending rates would depend on how sensitive the banks are to the BoG's steps. The government needs to rapidly inject some fiscal stimulus into industries most likely to suffer from the COVID-19 effects. COVID-19 has both had a positive and negative impact on Ghana. Ghana was not properly trained for the pandemic and was prepared. The effect on an important sector such as commerce needs to be debated, analyzed and the facts stated. Healthy and feasible solutions can be used as intelligence and knowledge resource to assist in the face of the pandemic.

Also, citizens of Ghana must exercise the highest degree of self-discipline is evident in the economic figures. The higher the level of self-discipline and civic duty that we uphold in following improved hygiene and social distancing protocols, the greater our ability to prevent major unemployment losses and its related difficulties. As a result of the coronavirus pandemic, we are already seeing a downturn in economic activity in the different sectors of the economy (Ndour, 2020).

The mass media, both electronic and print, should focus more on providing the citizenry with information. Relief items as well as other items should not only be issued in recognized regions and towns, but also in villages and other areas that are not necessarily in the spotlight, such as street homeless children, jail cells, and orphanage homes. The National Civic Education Commission (NCCE), Ghana Health Service (GHS), and other bodies may provide interviews or issue press releases (Amponsah \& Frimpong, 2020).

\section{Conclusion}

The pandemic has inspired the imagination of the entire human being to respond to emergencies. The transformation and improvement of customer services, the Internet industry, and other relevant sectors expedited. In a new round of growth opportunities, e-commerce, e-government, home office, virtual enterprise, online teaching, and other new types of business will begin. Also, the pandemic has highlighted the importance of the notion of human development. The global spread of this pandemic can be said to provide unprecedented exposure and potential for Ghana to become a promoter of the next era of infrastructure in Africa. 


\section{Limitations of the Study}

There are not enough prior research works on this topic and because the COVID-19 pandemic is an ongoing one, Ghana as a country keeps updating its protocols and combating solutions periodically.

\section{Conflicts of Interest}

The authors declare no conflicts of interest regarding the publication of this paper.

\section{References}

Abroquah, S. (2020). Impact of COVID-19 on Ghana's Agriculture-In the Eyes of a Youth Farmer. Impakter. https://impakter.com/covid-19-ghana-agriculture

Adoteye, D. (2020). Economic Impacts of COVID-19 on Ghana's Banking Industry-KPMG Ghana. KPMG.

https://home.kpmg/gh/en/home/insights/2020/05/economic-impact-of-covid-19.html

Africa Centre for Strategic Studies (2020). African Adaptations to the COVID-19 Response-Africa Centre. Washington DC: Africa Centre for Strategic Studies.

https://africacenter.org/spotlight/african-adaptations-to-the-covid-19-response

Aljazeera (2020). Ghanaians Welcome the End of the Three-Week Lockdown with Mixed Emotions.

https://www.aljazeera.com/news/2020/04/20/ghanaians-welcome-end-of-three-week-lo ckdown-with-mixed-emotions/

Amponsah, R., \& Frimpong, I. A. (2020). Ghana in the Face of COVID-19: Economic Impact of Coronavirus (2019-NCOV) Outbreak on Ghana. Open Journal of Business and Management, 8, 1404-1411. https://doi.org/10.4236/ojbm.2020.84089

Avila, C., Connor, C., \& Amico, P. (2013). Universal Coverage of Essential Health Services in Sub-Saharan Africa: Projections of Domestic Resources. HFG, USAID Health Finance and Governance (HFG).

https://www.hfgproject.org/universal-coverage-of-essential-health-services-in-sub-saha ran-africa-projections-of-domestic-resources-2

BBC Africa (2020). Virus Could Kill 190,000 in Africa “in One Year.” BBC News. 8 May. https://www.bbc.com/news/world-africa-52587408

Copenhagen Consensus Center (2020). Ghana Priorities: Report on COVID-19 Responses. Tewksbury, MA: Copenhagen Consensus Center.

https://www.copenhagenconsensus.com/publication/ghana-priorities-report-covid-19responses

Cromwell, A. (2020). All Final Year JHS Students to Be Given One Hot Meal a Day: Akufo-Addo. MyJoyOnline.com.

https://www.myjoyonline.com/news/national/all-final-year-jhs-students-to-be-given-o ne-hot-meal-a-day-akufo-addo

Danquah, M., \& Schotte, S. (2020). COVID-19 and the Socioeconomic Impact in Africa: The Case of Ghana. WIDER Background Note 2020/5, Helsinki: UNU-WIDER.

Debuysscher, J. (2020). Ghana Will Struggle with Impact of Covid-19 and Oil Price Shock. Credendo.

https://www.credendo.com/country-news/ghana-will-struggle-impact-covid-19-and-oi l-price-shock 
Deloitte (2020). The Impact of COVID-19 on East African Economies. Deloitte Tanzania. https://www2.deloitte.com/tz/en/pages/finance/articles/impact-of-covid19-on-ea-econ omies.html

Deloitte Ghana (2020). Economic Impact of the Covid-19 Pandemic on the Economy of Ghana. Deloitte Ghana.

https://www2.deloitte.com/gh/en/pages/about-deloitte/articles/economic-impact-of-Co vid-19-pandemic-on-the-economyof-ghana.html

Ditu, V. (2020). Silver Linings of the COVID-19 Crisis in Ghana: IRC. https://www.ircwash.org/blog/silver-linings-covid-19-crisis-ghana

ECA (2020). Economic Impact of the COVID-19 on Africa. http://www.uneca.org/sites/default/files/uploaded-documents/stories/eca analysis - c ovid-19 macroeconomiceffects.pdf

Ekeruche, M. A., \& Onyekwena, C. (2019). Is a Debt Crisis Looming in Africa? Washington DC: Brookings Institution.

http://www.brookings.edu/blog/africa-in-focus/2019/04/10/is-a-debt-crisis-looming-in -africa

Elliott, L. (2020). Prepare for the Coronavirus Global Recession. The Guardian, 15 Mar. https://www.theguardian.com/business/2020/mar/15/prepare-for-the-coronavirus-glob al-recession

Georgieva, K. (2020). Opening Remarks at High-Level Virtual Event on "Mobilizing with Africa”. IMF.

https://www.imf.org/en/News/Articles/2020/04/17/sp041720-2020-Spring-Meetings-Hi gh-Level-Virtual-Event-on-Mobilizing-with-Africa

Ghana Health (2020). COVID-19 Updates. Ghanahealthservice.org. https://ghanahealthservice.org/covid19

Hammond, M. (2020). Coronavirus: Kasapreko Reveals Mass Production of Hand Sanitisers Not for Profit. Yen.com.gh. Ghana News.

http://yen.com.gh/151245-coronavirus-kasapreko-produce-200000-bottles-sanitisers-aday-profit.html

Horowitz, J. (2020). The Global Coronavirus Recession Is Beginning. CNN. https:/edition.cnn.com/2020/03/16/economy/global-recession-coronavirus/index.html

Hoyt, L. D. M. (2020). Impact of COVID-19 in Sub-Saharan Africa. New Brunswick, NJ: Rutgers Global Health Institute.

https://globalhealth.rutgers.edu/news/impact-of-covid-19-in-sub-saharan-africa

IATA (2020). Africa \& Middle East-Urgent Emergency Support Requested for Airlines. https://www.iata.org/en/pressroom/pr/2020-03-19-01

IMF (2020). Public Sector Debt Statistics. http://www.imf.org/external/datamapper/GGXWDG_NGDP@WEO/OEMDC/ADVE C/WEOWORLD

Issahaku, H. (2020). Economic Impact of COVID-19 On Ghana: What Are the Channels? https://www.researchgate.net/publication/340117125 Economic Impact Of COVID19 On Ghana What Are The Channels

Kaledzi, I. (2020). “Ghana-Made” COVID-19 Test Kit That Gives Result in 15-20 Minutes. Africa Feeds.

https://africafeeds.com/2020/04/27/ghana-made-covid-19-test-kit-that-gives-result-in15-20-minutes

Karnon, J. (2020). The Case for a Temporary COVID-19 Income Tax Levy Now, during the Crisis. Applied Health Economics and Health Policy, 18, 335-337. 
Klomegah, K. K. (2020). COVID-19: Urgent Need for African Governments to Upgrade the Health Systems. IDN-InDepthNews. Analysis That Matters.

https://www.indepthnews.net/index.php/sustainability/health-well-being/3520-covid-1 9-urgent-need-for-african-governments-to-upgrade-the-health-systems

Knott, S. (2020). In Ghana, Drones Help Combat COVID-19. Voice of America-English. https://www.voanews.com/covid-19-pandemic/ghana-drones-help-combat-covid-19

Lexology (n.d.). Impact of COVID-19 on Ghana. Lexology. https://www.lexology.com/library/detail.aspx?g=c9f2808a-2dcb-49ef-b65e-8925de876fb $\underline{5}$

Mutize, M. (2020). African Countries Aren't Borrowing Too Much: They're Paying Too Much for Debt. The Conversation.

https://theconversation.com/african-countries-arent-borrowing-too-much-theyre-payi ng-too-much-for-debt-131053

Ndour, P. A. (2020). Economic Impact of the Covid-19 Pandemic on the Economy of Ghana, Republic of Ghana.

https://www.wathi.org/economic-impact-of-the-covid-19-pandemic-on-the-economyof-ghana-republic-of-ghana

OECD (2020a). COVID-19 and Africa: Socio-Economic Implications and Policy Responses. OECD.

http://www.oecd.org/coronavirus/policy-responses/covid-19-and-africa-socio-economi c-implications-and-policy-responses-96e1b282

OECD (2020b). COVID-19 and Beyond: How Can Africa's Health Systems Cope? Development Matters.

https://oecd-development-matters.org/2020/04/07/covid-19-and-beyond-how-can-afri cas-health-systems-cope

OECD/ATAF/AUC (2019). Revenue Statistics in Africa 2019. Paris: Éditions OCDE. https://doi.org/10.1787/9789264305885-en-fr

Ofori-Atta, K. (2020). Economic Impact of the COVID-19 Pandemic on the Economy of Ghana (pp. 1-22).

https://www.ccifrance-ghana.com/fileadmin/cru-1588064725/ghana/user upload/12-St atement Monday-Final.pdf.pdf

Poitras, C. (2020). Study Predicts COVID-19's Impact across Africa. New Haven, CT: Yale School of Medicine. https://medicine.yale.edu/news-article/24397

PROPARCO (2016). Air Transport: A Vital Challenge for Africa. https://www.proparco.fr/en/ressources/air-transport-vital-challenge-africa

Quakyi, N. K. (2020). The Logic of Ghana's Lockdown: Why Coronavirus Demands Special Attention. The Conversation.

https://theconversation.com/the-logic-of-ghanas-lockdown-why-coronavirus-demands -special-attention-135356

Rettner, R. (2020). Coronavirus Outbreak Officially Declared a Pandemic, WHO Says. Livescience.com. https://www.livescience.com/coronavirus-pandemic-who.html

Schneider, P., Pivodic, F., \& Yoo, K. J. (2020). How Much Health Financing Does Sub-Saharan Africa Need to Fight COVID-19 (Coronavirus)? Blogs.worldbank.org. https://blogs.worldbank.org/health/how-much-health-financing-does-sub-saharan-afri ca-need-fight-covid-19-coronavirus

UNCTAD (2019). Global Investment Trends Monitor (Series). Unctad.org. https://unctad.org/en/pages/publications/Global-Investment-Trends-Monitor-(Series). $\underline{\operatorname{aspx}}$ 
WHO (2020). Coronavirus Disease (COVID-19) Situation Report-181 Highlights Situation in Numbers (by WHO Region). Geneva: World Health Organization.

https://www.who.int/docs/default-source/coronaviruse/situation-reports/20200816-cov id-19-sitrep-209.pdf? sfvrsn=5dde1ca2 2

WHO Africa (2020). New WHO Estimates: Up to 190000 People Could Die of COVID-19 in Africa If Not Controlled. WHO, Regional Office for Africa.

https://www.afro.who.int/news/new-who-estimates-190-000-people-could-die-covid-1 9-africa-if-not-controlled

Wolfram, C. (2020). Subsidizing Electricity during a Pandemic: Lessons from Ghana. Energy Institute Blog.

https://energyathaas.wordpress.com/2020/07/20/subsidizing-electricity-during-a-pand emic-lessons-from-ghana/

Zhang, J., Nonvignon, J., \& Mao, W. (2020). How Well Is Ghana-With One of the Best Testing Capacities in Africa-Responding to COVID-19? Brookings.

https://www.brookings.edu/blog/future-development/2020/07/28/how-well-is-ghana-w ith-one-of-the-best-testing-capacities-in-africa-responding-to-covid-19 